\title{
TEMBANG “LIR-ILIR” BAGI GURU GUNA MENUMBUHKAN MOTIVASI BELAJAR DI PENDIDIKAN FORMAL (STUDI KASUS DI TK WAHID HASYIM DINOYO MALANG)
}

\author{
Endang Sih Pujiharti \\ e-mail: endangsihp@gmail.com \\ STAINU Malang, Jl. Raya Kepuharjo 18A Karangploso, Malang 65152
}

\begin{abstract}
Motivation to learn in early childhood are things that need attention from parents, teachers and the community, because it is generally a child is still not able to realize the wishes and needs related to learning without the help of others. Song "Lir-ilir" by Sunan Kalijaga, has a very important significance and depth that can be used as a source of inspiration by teachers to motivate children's learning, because teachers are the leaders for the students. This study aims to determine: 1) The meaning implied in the song "Lirilir"; 2) The role of teachers in schools with regard to early childhood learning motivation; 3) Efforts that teachers do to motivate learning early childhood by making the meaning of the song "Lir-ilir" as a source of inspiration. This study used a qualitative approach and descriptive method. The data was collected through interviews, observation and documentation. Result: 1 ) meaning contained in the song "Lir-ilir" very important and in-depth, 2) one of the teacher's role is very important in the learning process is as a motivator. Then the teacher demanded to motivate children's learning. 3) efforts undertaken teachers to motivate the child to learn to make meaning of the song "Lir-ilir" as a source of inspiration is: learn singing, learning through play, using props and iridescence of interest in learning.
\end{abstract}

Keywords: Meaning, Tembang, Motivation, Formal Education.

Abstrak

Motivasi belajar pada anak usia dini merupakan hal yang perlu mendapat perhatian dari para orang tua, guru maupun masyarakat, karena umumnya seorang anak masih belum bisa menyadari keinginan dan kebutuhannya sendiri berkaitan dengan belajar tanpa bantuan orang lain. Tembang "Lir-ilir" karya Sunan Kalijaga, mempunyai makna yang sangat penting dan mendalam yang dapat dijadikan sumber inspirasi oleh guru dalam menumbuhkan motivasi belajar anak, karena guru adalah pemimpin bagi anak didiknya. Penelitian ini bertujuan untuk mengetahui: 1) Makna yang tersirat dalam tembang "Lir-ilir"; 2) Peran guru di sekolah berkaitan dengan motivasi belajar anak usia dini; 3) Upaya-upaya yang dilakukan guru untuk menumbuhkan motivasi belajar anak usia dini dengan menjadikan makna tembang "Lir-ilir" sebagai sumber inspirasi. Penelitian ini menggunakan pendekatan kualitatif dan metode diskriptif. Pengumpulan data dengan wawancara, observasi dan dokumentasi. Hasil penelitian: 1) Makna yang terkandung dalam tembang "Lir-ilir" sangatlah penting dan mendalam, 2) Salah satu peran guru yang sangat penting dalam proses pembelajaran adalah sebagai motivator. Maka guru dituntut mampu menumbuhkan motivasi belajar anak. 3)Upaya-upaya yang dilakukan guru untuk menumbuhkan motivasi belajar anak dengan menjadikan makna tembang "Lir-ilir" sebagai sumber inspirasi adalah: belajar sambil bernyanyi, belajar sambil bermain, menggunakan alat peraga dan permainan warna yang menarik dalam pembelajaran.

Kata kunci: Makna, Tembang, Motivasi Belajar, Pendidikan Formal. 


\section{Pendahuluan}

Sekolah merupakan tempat berlangsungnya pendidikan formal, dimana disini terjadi proses penanaman nilai-nilai kepada anak didik yang dilakukan oleh guru sebagai pendidik. Taman Kanak-kanak adalah merupakan tempat pendidikan formal yang pertama yang dilalui oleh seorang anak, yaitu pendidikan bagi anak usia dini (umumnya rentang usia 4-6 tahun). Memandang anak sebagai investasi berharga, sangat beralasan karena masa usia prasekolah merupakan fase fundamental sehingga banyak ahli menyebutnya sebagai usia emas (golden ages). Pada usia tersebut, perkembangan intelektualnya sangat pesat. Berbagai hasil riset menunjukkan bahwa antara 50\% - 80\% otak anak berkembang pada rentang usia tersebut (Solehuddin dalam Rita Mariyana, 2010 : 10-11).

Pada tahapan perkembangan anak usia dini/TK (4-6 tahun), anak banyak mengalami perubahan yang sangat berarti. Pada kondisi normal, anak pada usia tersebut pada umumnya sudah bisa melakukan banyak hal yang luar biasa yang dapat membuat orang dewasa bangga. Mereka senang melakukan berbagai eksplorasi terhadap segala sesuatu yang dilihat, didengar maupun dirasakannya sebagai wujud dari keingintahuannya yang begitu besar. Sehingga merupakan tugas orang tua di sekitarnya untuk mengupayakan agar motivasi belajar pada anak tersebut bisa optimal. Mengingat perkembangan yang terjadi pada anak pada usia tersebut merupakan dasar bagi perkembangan selanjutnya.

Pada umumnya anak usia TK memiliki jiwa yang masih labil. Jika sedikit terjadi ketidaknyamanan, akan membuatnya mogok belajar atau bahkan tidak mau sekolah. Pemberian motivasi yang tepat akan sangat diperlukan baik dari orang tua, guru maupun lingkungan. Sehingga orang tua di sekitarnyalah yang berkewajiban untuk menumbuhkan motivasi belajar pada anak agar bisa tercapai tujuan yang diinginkan. Makin tepat motivasi yang diberikan, maka hasil belajar pasti juga akan optimal. Jadi motivasi akan senantiasa menentukan intensitas usaha belajar bagi anak (Sardiman A.M., 2011 : 84-85).

Ini berarti betapa pentingnya motivasi bagi anak dalam kegiatan belajar. Anak yang termotivasi akan menunjukkan minatnya untuk melakukan aktivitasaktivitas belajar, mempunyai usaha untuk meraih keberhasilan serta berusaha menyelesaikan tugas-tugas yang diberikan kepadanya dengan sebaik mungkin. Namun tidak selalu anak mempunyai motivasi yang tinggi dalam belajar. Biasanya pada masa kanak-kanak, anak belum menyadari keinginan dan kebutuhannya sendiri terkait dengan belajar tanpa bantuan orang lain. Motivasi belajar mereka tumbuh karena mendapat pengaruh sosial budaya yang ada di lingkungan atau karena mereka memiliki tanggung jawab untuk mengembangkan motivasi dari dalam diri mereka. Oleh karena itu di sekolah guru dituntut untuk mampu menumbuhkan motivasi belajar anak agar dapat tercapai tujuan yang telah ditetapkan.

Peranan guru sebagai motivator sangat penting artinya dalam meningkatkan kegairahan dan mengembangkan kegiatan belajar anak. Guru harus bisa memberikan rangsangan dan dorongan untuk menumbuhkan aktivitas dan kreativitas anak. Betapa pentingnya peran guru dalam memberikan motivasi belajar kepada anak, sehingga guru dituntut untuk memiliki kemampuan dan keterampilan untuk menciptakan kondisi belajar yang dapat membuat anak bisa belajar dengan senang dan nyaman demi tercapainya tujuan pembelajaran.

Sebuah tembang berjudul "Lir-ilir" hasil karya Kanjeng Sunan Kalijaga, salah seorang Wali Songo, merupakan sebuah tembang yang bukan hanya sekedar tembang dolanan atau pengantar tidur. Tetapi tembang tersebut mempunyai makna yang sangat penting dan begitu mendalam yang sekiranya dapat dijadikan sebagai sumber inspirasi oleh guru dalam 
menumbuhkan motivasi belajar anak didiknya.

"Lir-ilir" merupakan salah satu tembang Jawa yang digunakan oleh Sunan Kalijaga untuk melakukan dakwah Islam di Jawa. Syair tembang "Lir-ilir" adalah sebagai berikut: "Lir-ilir, lir-ilir, tandure wus sumilir. Tak ijo royo-royo, tak sengguh temanten anyar. Cah angon, cah angon, penekno blimbing kuwi, lunyu-lunyu penekno kanggo mbasuh dodotiro. Dodotiro-dodotiro, kumitir bedah ing pinggir. Dondomono jlumatono, kanggo sebo mengko sore. Mumpung padhang rembulane, mumpung jembar kalangane. Yo surako surak Iyo". Yang artinya dalam bahasa Indonesia adalah sebagai berikut: "Sayup-sayup, sayup-sayup bangun (dari tidur). Tanaman-tanaman sudah mulai bersemi, demikian menghijau bagaikan gairah pengantin baru. Anak-anak penggembala, tolong panjatkan pohon blimbing itu, walaupun licin tetap panjatlah untuk mencuci pakaian. Pakaianpakaian yang koyak disisihkan. Jahitlah benahilah untuk menghadap nanti sore. Selagi sedang terang rembulannya. Selagi sedang banyak waktu luang. Mari bersorak-sorak ayo.

Makna yang terkandung dalam tembang tersebut, dapat dijadikan sebagai sumber inspirasi oleh seorang guru karena guru mempunyai tanggung jawab sebagai "penggembala". Guru adalah pemimpin bagi anak didiknya. Segala macam bekal kehidupan berupa ilmu pengetahuan dan nilai-nilai yang harus ditanamkan dalam diri anak, sangatlah memerlukan kepiawaian guru dalam menerapkan strategi yang tepat untuk menumbuhkan motivasi pada diri anak agar mereka bisa mempunyai kemauan yang kuat dalam belajar agar tercapai apa yang diharapkan oleh semua pihak.

Berdasarkan uraian di atas, maka peneliti melakukan penelitian mengenai kaitan antara makna tembang "Lir-ilir" dengan tugas guru dalam menumbuhkan motivasi belajar anak usia dini di TK Wahid Hasyim Dinoyo Malang.

\section{Metode Penelitian}

Penelitian ini merupakan penelitian kualitatif (qualitatif research), dan menggunakan jenis penelitian diskriptif. Metode penelitian kualitatif digunakan untuk meneliti pada kondisi obyek yang alamiah dimana peneliti adalah sebagai instrumen kunci, pengambilan sampel sumber data dilakukan secara purposive dan snowball, teknik pengumpulan dengan triangulasi (gabungan), analisis data bersifat induktif /kualitatif dan hasil penelitian lebih menekankan makna daripada generalisasi (Sugiyono, 2010 : 15).

Lokasi penelitian di TK Wahid Hasyim Dinoyo Malang yang merupakan TK Islam yang bernafaskan Nahdlatul Ulama (NU). Sumber data utama dalam penelitian kualitatif adalah kata-kata dan tindakan, dan data tambahan seperti dokumen dan lain-lain. Yang menjadi sumber data adalah informan, yaitu kepala sekolah dan guru. Pengumpulan data adalah dengan wawancara, observasi dan dokumentasi. Untuk mendapatkan keabsahan data digunakan triangulasi, yaitu membandingkan dan pengecekan ulang terhadap data yang diperoleh. Menggunakan tiga langkah teknik triangulasi, yaitu triangulasi sumber, triangulasi metode, dan triangulasi melalui pengecekan antar waktu, sehingga diharapkan data yang berkaitan dengan pokok masalah penelitian semakin memperoleh standar kredibilitas tinggi.

\section{Hasil Penelitian dan PembahasanMakna yang Tersirat dalam Tembang "Lir-ilir"}

"Lir-ilir" merupakan salah satu tembang Jawa yang digunakan oleh Sunan Kalijaga untuk melakukan dakwah Islam di Jawa. Syair tembang "Lir-ilir" tersebut adalah sebagai berikut: "Lir-ilir, lir-ilir, tandure wus sumilir. Tak ijo royo-royo, tak sengguh temanten anyar. Cah angon, cah angon, penekno blimbing kuwi, lunyu-lunyu penekno kanggo mbasuh dodotiro. Dodotiro-dodotiro, kumitir bedah ing pinggir. Dondomono jlumatono, kanggo sebo mengko sore. Mumpung padhang 
rembulane, mumpung jembar kalangane. Yo surako surak Iyo".

Arti tembang "Lir-ilir" ini dalam bahasa Indonesia adalah sebagai berikut: "Sayup-sayup, sayup-sayup bangun (dari tidur). Tanaman-tanaman sudah mulai bersemi, demikian menghijau bagaikan gairah pengantin baru. Anak-anak penggembala, tolong panjatkan pohon blimbing itu, walaupun licin tetap panjatlah untuk mencuci pakaian. Pakaianpakaian yang koyak disisihkan. Jahitlah benahilah untuk menghadap nanti sore. Selagi sedang terang rembulannya. Selagi sedang banyak waktu luang. Mari bersorak-sorak ayo.

Tembang ini memiliki makna yang sangat penting dan mendalam yang perlu kita hayati agar dapat menginspirasi kita tentang hakikat kehidupan. Tembang karya Kanjeng Sunan Kalijaga ini memberikan hakikat kehidupan dalam bentuk syair yang indah. Pada baris pertama yang berbunyi lir-ilir,lir-ilir tandure wis sumiler, kata tandure yang mempunyai makna simbol yaitu menata sambil mundur. Makna simbol yang dimaksud oleh Sunan Kalijaga adalah dalam menata barisan. Dalam hal ini adalah menata sistem pemerintahan yang lebih baik dari sebelumnya, dengan melihat pengalaman atau kejadian pada masa lalu yang menjadi bahan untuk introspeksi diri dalam menata kembali kehidupan dengan memegang teguh syariat Islam sesuai dengan ajaran dakwah Sunan Kalijaga. Menata kehidupan pasti ada saja yang berubah arah menjadi penuh liku atau banyak godaan dalam masa kepemimpinannya. Oleh sebab itu, para pemimpin harus bisa menerima dengan lapang dada kritik atau saran dari masyarakat yang dipimpinnya.

Jika dikaitkan dengan dunia pendidikan dalam hal ini adalah TK Islam, hal ini bisa dijadikan sebagai sumber inspirasi bagi guru dalam menata proses pembelajaran. Seorang guru harus selalu memperbaiki diri dalam tugasnya sebagai seorang pendidik, dengan berkaca pada pengalaman masa lalu dan selalu terbuka dari kritik atau saran yang ada. Dalam melakukan tugasnya harus selalu berpegang teguh pada syariat Islam. Salah satu tugas pentingnya dalam mendidik anak TK adalah bagaimana guru bisa menumbuhkan motivasi belajar pada anak. Guru dituntut untuk memiliki keterampilan dalam menumbuhkan motivasi belajar anak agar proses pembelajaran dapat berjalan dengan lancar, sehingga akan dapat memberikan hasil yang optimal.

Tak ijo royo-royo, tak sengguh temanten anyar, jika diartikan makna tersebut tidak hanya merupakan jenis warna, tetapi Sunan Kalijaga menyimbolkan kata ijo royo-royo sebagai simbol yang tersirat untuk dakwah Islam. Makna ijo royo-royo dalam Islam disimbolkan dengan kenikmatan, suasana, kesenangan, dan ketenangan jiwa. Karena dalam Islam warna hijau disimbolkan dengan pakaian ahli surga. Dengan harapan para bangsawan dan masyarakat yang sebelumnya memeluk agama hindu dan budha akan merasakan kedamaian dan ketenangan jiwa setelah memeluk agama Islam. Sedangkan kata berikutnya temanten anyar berarti adanya kehidupan baru yang dijalani sepasang insan, yang dalam hal ini menyimbolkan sebagai orang yang baru masuk dan memeluk agama Islam. Demikian maraknya perkembangan masyarakat untuk masuk ke agama Islam, tetapi mereka belum mempunyai pemahaman yang mendalam mengenai agama barunya, hal ini disimbolkan seperti pengantin baru yang baru akan memulai kehidupan pernikahannya, di mana sepasang pengantin atau dalam hal ini adalah para kalangan pemimpin yang baru masuk dan memeluk agama Islam. Oleh karena itu, kalangan mualaf (orang yang baru memeluk Islam) dalam (Wiyono, 2007 : 415), masih memerlukan bimbingan atau pedoman untuk menjalaninya.

Kaitannya dengan proses belajar anak TK, mereka (anak-anak TK) adalah anak-anak yang baru mulai belajar tentang ilmu dan kehidupan. Sehingga ini adalah langkah awal seseorang belajar ilmu pengetahuan dan agama, yang bisa juga diibaratkan sebagai pengantin baru yang baru akan memulai kehidupan barunya. 
Agar proses pembelajaran berjalan dengan lancar dan bisa tercapai apa yang diinginkan, adalah tugas gurulah untuk bisa menumbuhkan motivasi belajar pada anak-anak tersebut agar mereka bisa belajar dengan nyaman dan senang. Karena umumnya seorang anak masih belum bisa menyadari keinginan dan kebutuhannya sendiri berkaitan dengan belajar tanpa bantuan orang lain.

Sedangkan (Chodim, 2013 : 182) juga menyatakan bahwa cah angon-cah angon, penekno blimbing kuwi mempunyai dua simbol yaitu cah angon yang berarti "gembala" secara harfiah, merujuk pada masyarakat kelas bawah atau kelompok masyarakat yang tidak terdidik. Dimana hidupnya adalah menjaga ternak yang sedang makan di peladangan atau padang rumput. Tetapi tentunya yang dimaksudkan oleh Sunan Kalijaga bukan gembala dalam pengertian seperti di atas, tetapi gembala dalam konteks ini adalah simbol dari penjaga rakyat. Mereka adalah pengembala yang mengendalikan rakyat. Para pemimpin yang disimbolkan oleh Sunan Kalijaga dengan pemilihan kata $c a h$ angon yaitu gembala. Kemudian kata yang selanjutnya yaitu blimbing yang mempunyai arti harfiah yaitu tumbuhan perdu berdaun kecil dan buahnya bergerigi lima buah (Wiyono, 2007 : 61). Dalam hal ini Sunan Kalijaga menyimbolkan blimbing sebagai Rukun Islam yang berjumlah lima buah yang terdiri dari syahadat, sholat, zakat, puasa dan haji bagi yang mampu. Artinya blimbing memiliki makna simbol yaitu Rukun Islam yang terdiri dari syahadat, sholat, zakat, puasa dan haji bagi yang mampu. Kelima hal tersebut dalam ilmu Islam memang bisa mensucikan harta dan jiwa raga manusia selama hidup di dunia sebagai bekal untuk mati, sehingga Sunan Kalijaga mengambil kata blimbing sebagai simbol untuk membersihkan harta dan jiwa manusia agar suci dan bersih dari dosa-dosa yang telah diperbuat.

Sehingga gembala dalam dunia pendidikan yang dimaksudkan adalah yang bertugas menggembalakan/memimpin anak-anak yaitu pendidik/guru. Guru sebagai pemimpin dan panutan bagi anak, harus mampu memberikan bekal pada anak yang berupa ilmu pengetahuan dan agama dengan berpegang teguh pada Rukun Islam. Agar bekal yang diberikan kepada anak bisa terserap dengan baik, maka motivasi belajar pada anak harus ditumbuhkan agar mereka memiliki kesadaran dan mau belajar dengan senang.

Selain itu (Chodim, 2013 : 180) juga menyatakan bahwa pada baris lunyulunyu penekno kanggo mbasuh dodotiro mempunyai satu simbol yaitu dodotiro yang berarti kain panjang yang dipakai para raja dan nara praja. Dodot juga digunakan sebagai selimut tidur. Jadi dodot merupakan kain yang amat penting bagi raja. Tetapi dalam agama khasanahbudaya Jawa disebut "ageman" atau pakaian. Agama Ageming Aji, agama merupakan pakaian raja. Sehingga dodot menyimbolkan pakaian yang penting untuk para bangsawan yang mana dalam konteks ini adalah pemerintah yang sedang memerintah pada saat itu diibaratkan pemimpin yang sedang tidak baik sistem pemerintahannya karena adanya perebutan kekuasaan dan korupsi besar-besaran, sehingga rakyatnya menjadi sengsara. Ini terjadi karena pemerintahan pada saat itu tidak memegang amanah rakyat dan tidak tangguh dalam penguatan agamanya. Oleh karena itu Sunan Kalijaga menyimbolkan dodot sebagai penilaian pada pemerintah. Sunan Kalijaga memilih kata dodot/ pakaian, karena pakaian adalah hal yang paling penting bagi seorang pemimpin. Jika pakaian itu kotor dan sudah lusuh maka Sunan Kalijaga mengingatkan untuk segera membasuhnya atau mensucikannya dengan blimbing yaitu berpegang teguh pada Rukun Islam.

Berkaitan dengan tugas guru disini, guru memang harus selalu memperbaiki metode/cara mengajar agar segala macam kesalahan dan kekurangan yang pernah dilakukan bisa diperbaiki dan terus diperbaiki. Terutama dalam menanamkan ilmu agama harus tetap berpegang teguh pada Rukun Islam, sehingga bisa tercapai tujuan yang 
diinginkan. Ini perlu dilakukan oleh seorang guru dalam menjalankan tugasnya sebagai seorang pendidik. Sehingga seorang guru harus selalu introspeksi berkaitan dengan tugas yang diembannya sebagai pemimpin dari anakanak, agar selalu dapat memberikan yang terbaik bagi anak didiknya.

Selanjutnya (Chodim, 2013 : 182)

juga menyatakan bahwa pada baris dondomono, jlumatono, kanggo sebo mengko sore terdapat satu simbol yaitu sore yang berarti matahari sudah tenggelam di ufuk barat (mengingatkan kepada segenap pemimpin dan masyarakat bahwa umur kalian sudah senja) di mana Sunan Kalijaga menyimbolkan peringatan itu dengan menggunakan kata sore. Kata sore dipilih oleh Sunan Kalijaga dalam liriknya, karena pada waktu sore pastilah matahari sudah saatnya terbenam di ufuk barat, disimbolkan dengan keadaan manusia yang sudah memasuki usia senja. Jika dipelajari lebih dalam kehidupan orang Jawa sangat syarat akan makna positif kehidupan. Tuhan telah mengatur kehidupan bagi semua makhluk hidup, termasuk manusia. Setiap hari melihat banyak orang yang keluar rumah untuk bekerja mencari penghidupan yang lebih baik. Pagi hari mereka keluar rumah untuk bekerja dan sore pulang dengan kondisi yang lebih baik. Di sini alasan Sunan Kalijaga memilih kata sore sebagai simbol jika manusia telah pulang menghadap Allah SWT maka harus dalam keadaan yang baik atau khusnul khotimah.

Ini artinya sangat penting untuk membekali anak-anak ilmu sejak dini. Ilmu pengetahuan dan ilmu agama sangat berguna bagi anak, untuk mempersiapkan kehidupan yang baik bagi mereka baik dunia dan akhirat. Ilmu adalah sebagai bekal bagi kehidupan manusia. Tujuan pendidikan akan tercapai, apabila guru mempersiapkan proses pembelajaran dengan baik sehingga anak akan dapat belajar dengan efektif. Artinya motivasi pada anak harus ditumbuhkan agar proses pembelajaran dapat berjalan dengan lancar dan tercapai apa yang diinginkan. Dan ilmu yang didapatkan juga akan berguna bagi kehidupan mereka di dunia dan akhirat.

Pada baris terakhir yang berbunyi mumpung padhang rembulane, mumpung jembar kalangane yang mempunyai satu simbol yaitu rembulan yang menyimbolkan situasi terang dan lapang, terang berartikan rembulan yang letaknya berada paling atas dalam kehidupan manusia. Dapat disimbolkan sebagai pemimpin (yang dijunjung oleh rakyat) karena letaknya berada paling atas sebagai pemimpin rakyat. Selain itu, kata rembulan merupakan suatu yang terang, karena banyak pemimpin dan rakyat yang berpindah agama ke Islam (Chodim, 2013 : 178) sehingga Islam mempunyai banyak pengikut.

Berkaitan dengan pendidikan, belajar sejak dini sangatlah perlu dilakukan. Selagi masih usia anak-anak harus kita optimalkan perkembangannya mengingat masa kanak-kanak adalah masa emas dalam perkembangan manusia. Oleh karena itu, selagi masih ada kesempatan harus disiapkan anak-anak menjadi pribadi yang berilmu dan beragama dengan berpegang teguh pada ajaran Islam. Manusia tidak boleh menyianyiakan kesempatan yang ada. Adalah menjadi tugas guru TK untuk mempersiapkan anak menjadi pribadi yang baik sebagai bekal kehidupannya. Sehingga guru-guru ini dituntut untuk bisa menumbuhkan motivasi pada diri anak untuk belajar yang baik agar tercapai apa yang diinginkan.

Begitu mendalam makna yang terkandung dalam tembang "Lir-ilir" yang tersebut di atas, yang sekiranya sangat cocok digunakan sebagai sumber inspirasi bagi seorang guru karena guru adalah merupakan orang yang mempunyai tanggung jawab sebagai "penggembala", dalam arti guru harus bisa menjadi panutan dan membawa anak didiknya ke jalan yang lurus untuk menjadikannya sebagai anak yang berilmu dan bertaqwa. Segala macam bekal kehidupan berupa ilmu pengetahuan dan nilai-nilai yang harus ditanamkan dalam diri anak, sangatlah memerlukan kepiawaian guru dalam menerapkan strategi yang tepat 
dalam menumbuhkan motivasi belajar pada diri anak agar mereka bisa mempunyai kemauan yang kuat dalam belajar agar tercapai apa yang diharapkan oleh semua pihak.

\section{Peran Guru di Sekolah Berkaitan dengan Motivasi Belajar Anak Usia Dini}

Motivasi mempunyai peran yang sangat penting bagi anak dalam kegiatan belajar. Anak yang termotivasi akan menunjukkan minatnya untuk melakukan aktivitas-aktivitas belajar, mempunyai usaha untuk meraih keberhasilan serta berusaha menyelesaikan tugas-tugas yang diberikan kepadanya dengan sebaik mungkin. Namun tidak selalu anak mempunyai motivasi yang tinggi dalam belajar. Biasanya pada masa kanak-kanak, motivasi belajar tumbuh karena mendapat pengaruh sosial budaya yang ada di lingkungan atau karena mereka memiliki tanggung jawab untuk mengembangkan motivasi dari dalam diri mereka. Oleh karena itu di sekolah guru dituntut untuk mampu menumbuhkan motivasi belajar anak agar dapat tercapai tujuan yang telah ditetapkan.

Salah satu peran guru di sekolah adalah sebagai motivator dalam proses pembelajaran. Peranan guru sebagai motivator sangat penting artinya dalam meningkatkan kegairahan dan mengembangkan kegiatan belajar anak. Guru harus bisa memberikan rangsangan dan dorongan untuk menumbuhkan aktivitas dan kreativitas anak. Betapa pentingnya peran guru dalam memberikan motivasi belajar kepada anak, sehingga guru dituntut untuk memiliki kemampuan dan keterampilan untuk menciptakan kondisi belajar yang dapat membuat anak bisa belajar dengan senang dan nyaman demi tercapainya tujuan yang telah ditetapkan.

Prey Katz dalam (Sardiman, 2011 : 143) menggambarkan peranan guru sebagai komunikator, sahabat yang dapat memberikan nasihat-nasihat, motivator sebagai pemberi inspirasi dan dorongan, pembimbing dalam pengembangan sikap dan tingkah laku serta nilai-nilai, orang yang menguasai bahan yang diajarkan. Ini artinya seorang guru harus bisa berkomunikasi dengan anak dalam posisinya sebagai seorang guru, tetapi di lain pihak harus bisa juga berperan sebagai sahabat yang dapat memberikan nasihat-nasihat kepada anak didiknya. Selain itu guru harus bisa memberikan motivasi, membimbing, mengarahkan, dan mengembangkan sikap dan tingkah laku serta nilai-nilai misalnya dengan memberikan tauladan atau melalui pembiasaan sikap dan nilai-nilai yang baik. Serta dituntut pula seorang guru menguasai bahan/materi yang akan diajarkan.

$\begin{array}{ccc}\text { Federasi } & \text { dan } & \text { Organisasi } \\ \text { Profesional } & \text { Guru } & \text { Sedunia, }\end{array}$
mengungkapkan bahwa peranan guru di sekolah tidak hanya sebagai transmiter dari ide tetapi juga berperan sebagai transfomer dan katalisator dari nilai dan sikap. Sedangkan Sardiman menjelaskan salah satu peran guru yaitu sebagai motivator, merupakan peran yang penting artinya dalam rangka meningkatkan kegairahan dan pengembangan kegiatan belajar. Guru harus dapat merangsang dan memberikan dorongan untuk mendinamisasikan potensi, menumbuhkan swadaya (aktivitas) dan daya cipta (kreativitas) anak. Peran ini sangat penting karena menyangkut esensi pekerjaan mendidik yang membutuhkan kemahiran sosial, menyangkut performance dalam arti personalisasi dan sosialisasi diri (Sardiman, 2011 : 144145).

Dari pendapat di atas terlihat bahwa salah satu peran guru yang sangat penting adalah sebagai motivator bagi anak. Berhasil atau tidaknya anak menyerap apa yang disampaikan oleh guru, sangatlah tergantung pada sikapnya ketika dia mengikuti proses pembelajaran. Seorang anak yang antusias dalam mengikuti pelajaran, maka pasti dia juga akan bisa menyerap apa yang disampaikan oleh guru. Tetapi sebaliknya anak yang tidak mempunyai motivasi dalam belajar pasti dia tidak akan mendapatkan apa-apa. Sehingga disini merupakan tugas dan peran guru dalam menumbuhkan motivasi belajar pada anak. Di sisi lainpara pakar 
meyakini bahwa setiap anak dilahirkan dengan motivasi untuk belajar. Sehingga secara alami setiap anak memiliki sifat ingin tahu untuk mengeksplorasi lingkungannya. Oleh sebab itu, anak-anak akan selalu tertarik dan terdorong untuk mengetahui apa saja yang ditemukannya. Anak memang selalu tertarik pada segala sesuatu yang baru dan berbeda dengan dunia yang dimilikinya (Akbar, 2006 : 92).

Dari uraian di atas terlihat dengan jelas bahwa guru merupakan aktor kunci dalam menumbuhkan motivasi belajar pada anak di sekolah. Semakin tepat cara pemberian motivasi yang digunakan, akan lebih dapat membuat anak semakin bersemangat di dalam belajar. Artinya semakin mudah pula untuk mencapai tujuan yang diinginkan.

\section{Upaya-upaya Menumbuhkan Motivasi Belajar dengan Menjadikan Makna Tembang "Lir-ilir" sebagai Sumber Inspirasi}

Dari hasil yang diperoleh di lapangan, ada beberapa upaya yang dilakukan guru TK Wahid Hasyim untuk menumbuhkan motivasi belajar anak adalah sebagai berikut:

1) Belajar sambil bernyanyi

Nyanyian pasti mempunyai daya tarik tersendiri bagi seorang anak. Seorang anak akan lebih mudah mengingat kata-kata/sesuatu yang terngiang di telinga mereka lewat sebuah lagu. Lagu yang ia dengarkan akan membekas dalam hati mereka sehingga nilai-nilai yang terkandung di dalamnya akan lebih mudah ditanamkan kepada anak. Itulah sebabnya guru-guru di TK Wahid Hasyim menggunakan cara tersebut untuk menumbuhkan motivasi belajar anak.

Friederich Wilhelm Froebel (Jerman) dianggap sebagai ayah dari pendidik anak usia bayi, selain itu dikenal karena menciptakan "garden of children" atau "kindergarten" (Taman Kanak-kanak), merancang kurikulum yang meliputi pekerjaan, atau kegiatan seni dan keahlian serta pembangunan atau konstruksi. Selain itu juga menyanyi, permainanpermainan, bahasa dan aritmatika (Soemiarti, 2008 : 6-7). Ini artinya menyanyi memang benar-benar cara yang efektif digunakan untuk menarik perhatian anak dalam belajar di TK. Nyanyian merupakan alat yang menarik bagi anak untuk menumbuhkan motivasi mereka dalam belajar.

Sedangkan dalam Kurikulum 2004 dengan standar kompetensi ditegaskan bahwa tujuan pendidikan pada anak usia dini adalah membantu anak didik mengembangkan berbagai potensi baik psikis dan fisik yang meliputi moral dan nilai-nilai agama, sosial-emosional, kognitif, bahasa, fisik/motorik, kemandirian maupun seni untuk siap memasuki pendidikan dasar (Uyu W. Mubiar A, 2011 : 5). Disini terlihat bahwa tujuan pendidikan anak usia dini adalah membantu mengembangkan potensi anak baik fisik maupun psikis. Salah satu potensi tersebut adalah seni yang ada dalam diri anak, dimana termasuk di dalamnya adalah seni suara atau menyanyi. Hal ini disebabkan karena melalui seni suara/menyanyi dapat melatih kemampuan bahasa, kognitif maupun emosional anak.

Sedangkan terkait dengan motivasi, alunan seni suara yang indah pasti akan dapat menarik minat dan perhatian anak untuk ikut terlibat dalam kegiatan yang sedang berlangsung di hadapannya, dalam hal ini adalah kegiatan pembelajaran yang ada di sekolah. Sehingga sangatlah tepat apabila guru di TK menggunakan metode pembelajaran sambil bernyanyi, karena pasti akan menarik perhatian anak.

2) Belajar sambil bermain

Dunia anak adalah dunia bermain, sehingga sangatlah tepat apabila guru menanamkan nilai-nilai pada anak melalui sebuah permainan. Para pendidik menyadari bahwa bermain adalah suatu kegiatan yang sangat penting bagi anak-anak usia 
muda karena merupakan cara/jalan bagi anak untuk mengungkapkan pemikiran, perasaan serta cara mereka menjelajah dunia lingkungannya. Bermain juga membantu anak dalam menjalin hubungan sosial antar anak, dan melalui permainan tertentu guru dapat meningkatkan mutu pendidikan melalui kegiatan bermain di sekolah (Soemiarti, 2008 : 112). Bermain merupakan pendekatan dalam melaksanakan kegiatan pendidikan anak usia dini, dengan menggunakan strategi, metode, materi/bahan dan media yang menarik agar mudah diikuti oleh anak (Uyu W. Dan Mubiar A., 2011 : 14).

Tujuan pendidikan anak usia dini secara khusus adalah terciptanya tumbuh kembang yang optimal, terciptanya pengetahuan, ketrampilan dan sikap orang tua yang optimal serta mempersiapkan anak masuk pendidikan dasar. Sedangkan tujuan berdasarkan tinjauan aspek didaktis psikologis meliputi : 1) menumbuhkembangkan pengetahuan, sikap dan ketrampilan agar mampu menolong diri sendiri (self help), yaitu mandiri dan bertanggung jawab terhadap diri sendiri seperti mampu merawat dan menjaga kondisi fisiknya, mampu mngendalikan emosinya dan mampu membangun hubungan dengan orang lain; 2) Meletakkan dasar-dasar tentang bagaimana seharusnya belajar (learning how to learn). Hal ini sesuai dengan paradigma baru dunia pendidikan melalui empat pilar pendidikan yang dicanangkan oleh UNESCO, yaitu learning to know, learning to do, learning to be dan learning to live together yang dalam implementasinya di Taman Kanak-kanak dilakukan melalui pendekatan learning by playing, belajar yang menyenangkan (joyful learning) serta menumbuhkembangkan ketrampilan hidup (life skill) sederhana secara dini (Uyu W. Dan Mubiar A., 2011 : 10).

Belajar sambil bermain akan membantu anak dalam memberikan dasar bagi perkembangan pengetahuan, sikap serta keterampilannya. Dengan bermain, anak akan diajak untuk berpikir, berkreasi dan berbuat sesuatu dan belajar menyesuaikan diri dengan lingkungannya. Permainan yang menarik dan sesuai dengan tahap perkembangan anak, akan banyak membantu dalam menumbuhkan motivasinya dalam mempelajari sesuatu. Melalui sebuah permainan akan lebih menarik dan menyenangkan bagi anak di dalam mempelajari sesuatu mengingat masa kanak-kanak memang adalah masa bermain. Bentuk-bentuk permainan yang menarik akan membuat anak lebih antusias dalam belajar. Bentukbentuk bermain meliputi: bermain sosial, bermain dengan benda, dan bermain sosio dramatis.

3) Menggunakan Alat Peraga

Peraga mempunyai daya tarik tersendiri bagi seorang anak dalam belajar, itulah sebabnya guru-guru di TK Wahid Hasyim menggunakan peraga untuk menumbuhkan motivasi belajar anak di TK tersebut.

Alat peraga sebagai media dalam proses belajar mengajar mempunyai peranan yang sudah tidak diragukan lagi karena dapat menghemat waktu belajar, memudahkan pemahaman, meningkatkan perhatian siswa, meningkatkan aktivitas siswa, mempertinggi daya ingat siswa (Sardiman, 2011 : 205). Itulah sebabnya penggunaan alat peraga ini memang sangat tepat digunakan pada anak-anak karena dapat menumbuhkan motivasi pada diri mereka dalam proses pembelajaran.

Alat peraga merupakan salah satu media yang dapat digunakan oleh guru dalam proses pembelajaran di kelas. Peranan alat peraga/media ini akan terlihat apabila penggunaanya sejalan dengan isi dari tujuan pengajaran, sehingga pencapaian tujuan ini akan lebih efektif dan efisien. Tetapi apabila digunakan tidak 
sesuai dengan tujuan pengajaran, maka bisa jadi akan malah menjadi penghambat tercapainya tujuan. Alat peraga/media ini bisa berguna sebagai alat bantu maupun sebagai sumber belajar.

Syaiful B. dan Aswan Z. membagi media berdasarkan jenisnya menjadi media auditif, media visual dan media audio visual. Media auditif hanya mengandalkan pada kemampuan suara saja, media visual hanya mengandalkan pada penglihatan sedangkan media audiovisual mengandalkan pada suara dan gambar. Jenis yang ketiga ini mempunyai kemampuan yang lebih baik sebagai media (Syaiful B. Dan Aswan Zain, 2010 : 124).

Dalam pembelajaran di Taman Kanak-kanak, alat peraga/media yang menarik pastilah akan bisa merangsang minat anak untuk mengikuti proses pembelajaran di kelas. Ketertarikan anak pada apa yang dilakukan/diberikan guru akan merangsang/memotivasi anak untuk bisa mengikuti apa yang diberikan guru di kelas sebagai upaya untuk meningkatkan/mengoptimalkan perkembangannya.

4) Permainan Warna yang Menarik

Warna-warna yang menarik akan membuat gairah belajar anak menjadi lebih besar. Guru-guru di TK Wahid Hasyim menggunakan permainan warna yang menarik untuk menumbuhkan motivasi belajar pada anak.

Jurnal Sriti Mayang Sari, Dosen Desain Interior Fakultas Seni dan Desain Universitas Kristen Petra Surabaya tahun 2004, meneliti mengenai peran warna interior terhadap perkembangan dan pendidikan Anak di Taman Kanakkanak. Seorang anak pastilah tertarik pada sesuatu yang memiliki warnawarna menarik. Baik itu warna-warna pernak-pernik yang menghiasi kelas mereka, maupun alat peraga yang digunakan sebagai media pembelajaran. Warna-warna yang menarik pasti akan membuat mereka lebih antusias untuk belajar dan menambah rasa keingintahuan mereka terhadap apa yang disampaikan oleh guru atau hal-hal lain yang ada di sekitar mereka. Oleh karena itu guru harus pandai menarik perhatian anak melalui permainan warna dalam proses pembelajaran.

Ruangan kelas di TK harus menarik, penuh dengan materi yang berwarna-warni, tetapi tetap tertata rapi (Soemiarti, 2008 : 158). Ini artinya warna-warna yang menarik dapat digunakan untuk merangsang/menumbuhkan motivasi anak di dalam belajar. Ketertarikan anak terhadap materi yang disajikan dengan warna yang menarik, akan dapat merangsang tumbuhnya/meningkatnya motivasi mereka dalam belajar.

\section{Kesimpulan}

Makna yang terkandung dalam tembang "Lir-ilir" sangat penting dan mendalam. Merupakan seruan Sunan Kalijaga, salah seorang Wali Songo yang mengajak kita untuk bangkit dari keterpurukan dan sifat malas untuk belajar. Seruan ini ditujukan kepada para pemimpin agar bisa membawa makmumnya menuju jalan yang benar dengan memegang teguh pada Rukun Islam. Walaupun susah dan banyak rintangan tetapi harus tetap dilakukan sebagai bekal untuk kehidupan dan kebahagiaan yang hakiki. Selagi masih ada waktu dan kesempatan. Makna ini dapat digunakan sebagai sumber inspirasi oleh seorang guru dalam mendidik dan membimbing anak didiknya.

Salah satu peran guru yang sangat penting dalam proses pembelajaran adalah sebagai motivator bagi anak. Berhasil atau tidaknya anak menyerap apa yang disampaikan oleh guru, sangatlah tergantung pada sikapnya ketika dia mengikuti proses pembelajaran. Seorang anak yang antusias dalam mengikuti pelajaran, maka pasti dia juga akan bisa menyerap apa yang disampaikan oleh 
guru. Tetapi sebaliknya anak yang tidak mempunyai motivasi dalam belajar pasti dia tidak akan mendapatkan apa-apa. Sehingga tugas gurulah untuk menumbuhkan motivasi pada anak agar tercapai apa yang diinginkan.

Upaya-upaya yang dilakukan guru TK Wahid Hasyim untuk menumbuhkan motivasi belajar anak dengan menjadikan makna tembang "Lir-ilir" sebagai sumber inspirasi adalah sebagai berikut: belajar sambil bernyanyi, belajar sambil bermain, menggunakan alat peraga dan permainan warna yang menarik dalam pembelajaran.

\section{Saran}

Diharapkan bagi pengelola pendidikan anak usia dini agar memperhatikan motivasi belajar anak didiknya terutama yang berkaitan dengan bagaimana cara menumbuhkan motivasi belajar pada anak, mengingat betapa pentingnya motivasi belajar untuk tercapainya tujuan yang diinginkan. Sedangkan bagi guru kelas pendidikan anak usia dini, sebagai orang yang bertanggung jawab terhadap keberhasilan proses belajar mengajar di kelas, sebaiknya menjadikan makna tembang "Lir-ilir" sebagai sumber inspirasi untuk menumbuhkan motivasi belajar pada anak didiknya guna tercapainya tujuan yang diinginkan. Bagi peneliti selanjutnya disarankan untuk melakukan pengkajian lebih mendalam tentang motivasi belajar anak usia dini.

\section{Daftar Pustaka}

Akbar. 2006. Psikologi Perkembangan Anak. Jakarta: PT. Grasindo. Cetakan keenam.

Djamarah, Syaiful Bahri dan Zain, Aswan. 2010. Strategi Belajar Mengajar. Jakarta: PT. Rineka Cipta. Cetakan keempat.

Mariyana, Rita dkk. 2010. Pengelolaan Lingkungan Belajar. Jakarta: Kencana. Cetakan ke-1.

Mayang Sari, Sriti. 2004. Peran Warna Interior Terhadap Perkembangan dan Pendidikan Anak di Taman Kanak-kanak. Jurnal Dimensi Interior. Vol. 2. No. 1.

Patmonodewo, Soemiarti. 2008. Pendidikan Anak Prasekolah. Jakarta: PT. Rineka Cipta. Cetakan kedua.

Sardiman, A.M. 2011. Interaksi dan Motivasi Belajar Mengajar. Jakarta: PT. Raja Grafindo Persada.

Sugiyono. 2009. Metode Penelitian Pendidikan. Bandung: Alfabeta. Cetakan ke-7.

Wahyudin, Uyu dan Agustin, Mubiar. 2011. Penilaian Perkembangan Anak Usia Dini. Bandung: PT. Refika Aditama. Cetakan kesatu.

Wiyono. 2007. Kamus Bahasa Indonesia Lengkap. Jakarta: Akar Media. 